\section{AB0002 ONE OF SUSCEPTIBILITY LOCI FOR RHEUMATOID ARTHRITIS IS LYING INSIDE 14Q11.1-11.2 BANDS SUGGESTED BY A LINKAGE STUDY}

MY Krylov, SA Finigenova, MA Moshnina, EY Samarkina, VA Maykotkin. Epidemiology and Genetics, Institute of Rheumatology, Moscow, Russia

\subsection{6/annrheumdis-2001.91}

Background Rheumatoid arthritis (RA) is a complex disorder with genetic component that has been suggested by familial aggregation, twin studies, and segregation analysis. Early we show that the type of the inheritance of RA corresponded to a single autosomal two-alleles locus model with incomplete penetrance. This model was used in our study for parametric linkage analysis candidate genes: HLA, T-cell receptors (TCRA, TCRB, TCRD), Col1A2, $\mathrm{Col}^{2} \mathrm{~A} 1$. Lod scores were negative (less than 2.0) for HLA, TCRB, Col1A2 and $\mathrm{Col}^{2} \mathrm{~A} 1$ loci.

Objectives To identify a new RA susceptibility genes to lying inside 14 q11.1-11.2 chromosomal segment.

Methods We conducted a study in 25 multiplex RA families, 1015 of them were informative for linkage analysis. The polymorphism of TCRD and TCRA genes, D14S261 and D14S283 microsatellites were investigated by single-strand conformation polymorphism. The TCRD point variation (TCRDpv) was confirmed by restriction fragment length polymorphism.

Results Lod scores (LS) were calculated at standard recombination fractions. The summarised LS for informative families are presented below: D14S261 - LS $=+1.50(\mathrm{RF}=0)$, TVRD $\mathrm{LS}=+1.65(\mathrm{RF}=0.05), \mathrm{TCRDpv}-\mathrm{LS}=+0.65(\mathrm{RF}=0)$, TCRA $-\mathrm{LS}=+0.94(\mathrm{RF}=0), \mathrm{D} 14 \mathrm{~S} 283-\mathrm{LS}=+0.1(\mathrm{RF}=$ 0.1 ).

Conclusion These findings show evidence that 14 q11.1-11.2 are bands which may contain one of the RA susceptibility genes.

This is study was supported by Russian Foundation basic Research grant N 99-04-48643.

\section{AB0003 LACK OF ASSOCIATION BETWEEN RHEUMATOID ARTHRITIS AND VITAMIN D RECEPTOR POLYMORPHISMS IN KOREANS}

1J Choe, ${ }^{1} \mathrm{CG}$ Kim, ${ }^{1} \mathrm{YH}$ Song, ${ }^{2} \mathrm{SG} \mathrm{Kim},{ }^{2} \mathrm{CH}$ Jeon, ${ }^{3} \mathrm{OD}$ Kim. ${ }^{1}$ Department of Internal Medicine; ${ }^{2}$ Department of Clinical Pathology; ${ }^{3}$ Department of Radiology, Catholic University of Daegu School of Medicine, Daegu, Korea

\subsection{6/annrheumdis-2001.92}

\section{Background}

Objectives To determine whether 1) the frequency of vitamin D receptor (VDR) polymorphisms in the rheumatoid arthritis (RA) patient group is different from that of the control group; and 2) there is a relationship between VDR genotypes vs the radiographic severity of RA and bone mineral density (BMD) in RA patients in Korea.

Methods The VDR genotype was determined by using polymerase chain reaction and by digestion with three restriction enzymes Taq I and Bsm I in elderly female controls $(\mathrm{n}=78)$ and RA patients $(n=97)$. Hand X-rays were scored by Larsen's method and femoral neck BMD was measured by dual energy X-ray absorptiometry in RA patients.

Results VDR genotypic distributions in Koreans were much different from those of Caucasians in both the control and RA group. In particular, "tt" and "BB" alleles were very rare, unlike the distribution in Caucasian population. No significant differences in VDR genotypic frequency were observed between the control group and the RA group. In addition, no significant relationship was found between the VDR genotypes and radiographic scores of RA, nor between the VDR genotypes and $\mathrm{BMD}$ in RA patients.

\begin{tabular}{|c|c|c|}
\hline & Controls $(n=78)$ & RA patients $(n=97)$ \\
\hline тT & $70(90 \%)$ & $87(90 \%)$ \\
\hline Tt & $8(10 \%)$ & $10(10 \%)$ \\
\hline tt & $0(0 \%)$ & $0(0 \%)$ \\
\hline BB & $0(0 \%)$ & $1(1 \%)$ \\
\hline $\mathrm{Bb}$ & $9(12 \%)$ & $12(12 \%)$ \\
\hline bb & $69(88 \%)$ & $84(87 \%)$ \\
\hline
\end{tabular}

Conclusion The distribution of VDR polymorphisms in RA patients is not different from that of the controls. The VDR polymorphisms do not significantly correlate with the radiographic severity of RA, nor with BMD in Korean RA patients.

\section{AB0004 MOLECULAR ANALYSIS OF HLA-B27 HAPLOTYPES IN THE CROATIAN POPULATION}

${ }^{1} \mathrm{Z}$ Grubic, ${ }^{2} \mathrm{P}$ Peric, ${ }^{1} \mathrm{~V}$ Kerhin-Brkljacic, ${ }^{1} \mathrm{E}$ Cecuk-Jelicic, ${ }^{1} \mathrm{R}$ Zunec, ${ }^{1} \mathrm{~A}$ Kastelan. ${ }^{1}$ Tissue Typing Center, ${ }^{2}$ Clinic of Rheumatology, University Hospital Zagreb, Zagreb, Croatia

\subsection{6/annrheumdis-2001.93}

Background HLA-B27 is strongly associated with ankylosing spondylitis (AS) and most studies in the last years suggest that B27 molecule itself could be directly involved in the aetiology of AS. On the other hand, some studies suppose existence of additional gene involved in AS. That gene could also be located inside the HLA region.

Objectives The aim of this study was to analyse the polymorphism at neighbouring HLA-loci in the group of B27 positive AS patients and B27 positive unrelated healthy individuals.

Methods All 52 B27 positive AS patients and 32 B27 positive controls were DNA typed for B27 subtypes, Cw and DRB1 alleles by PCR-SSP method.

Results Three different ancestral haplotypes were found in the patient group: $\mathrm{B} * 2705-\mathrm{Cw}^{*} 0202$ (82.3\%), B*2705-Cw*0102 $(13.8 \%)$, and $\mathrm{B}^{*} 2705-\mathrm{Cw}^{*} 0202$ (6.9\%). Comparison between patients and controls did not show any significant differences. Analysis of distribution of DRB1 alleles revealed that DRB1*01 allele was the most present allele among $\mathrm{B} * 27$ positive individuals $(21.5 \%$ in AS group and $23.4 \%$ in control group). DRB1\%0301 allele was significantly more frequent in patients than in controls $(9.6 \%$ vs. $1.6 \% ; \mathrm{p}=0.03)$, while lower frequency of DRB1*0701 allele among patients is marginally significant $(1.9 \%$ vs $7.8 \% ; \mathrm{p}=0.055)$. Furthermore, the linkage disequilibrium between observed between second most frequent allele (DRB1*16) and B*27 has to be noted as characteristic for our population.

Conclusion Our results suggest that HLA-Cw alleles are not involved in aetiology of AS. The possible role of some DRB1 alleles, as well as non HLA markers around HLA-B locus in necessary to confirm on a larger group of B27 positive individuals. 